\title{
Time to Maturity and Volume Effects on Volatility: Evidence from NSE Futures Market
}

\author{
P. Sakthivel ${ }^{1}$, G. Raghuram ${ }^{2}$, K. Veerakumar ${ }^{1} \&$ B. Sumathisri ${ }^{1}$ \\ ${ }^{1}$ Department of Commerce and Management Studies, Srinivasa Ramanujan Centre, SASTRA University, \\ Kumbakonam, Thanjavur, Tamil Nadu, India \\ ${ }^{2}$ School of Management, SASTRA University, Thanjavur, Tamil Nadu, India \\ Correspondence: P. Sakthivel, Department of Commerce and Management Studies, Srinivasa Ramanujan Centre, \\ SASTRA University, Kumbakonam, Thanjavur, Tamil Nadu, India. E-mail: sakthivel@mba.sastra.edu
}

Received: June 11, 2014 Accepted: August 8, 2014 Online Published: August 15, 2014

doi:10.5539/ass.v10n18p75

URL: http://dx.doi.org/10.5539/ass.v10n18p75

\begin{abstract}
The study empirically examines the relationship between time to maturity and price volatility in NSE futures market by employing GARCH framework. It also investigates 'Mixture of Distribution Hypothesis' which is based on the relationship between futures price volatility and volume. For the analysis, data on daily closing pricing of Nifty Futures, volume and open interest are collected for the period from $4^{\text {th }}$ July, 2003 to $28^{\text {th }}$, November, 2012. Besides, the study has chosen 10 individual stock futures and collected their daily closing price, volume and open interest data. The study uses near-month contract data as most trading activities have taken place in near-month contracts. The study considers open interest and volume as measures of futures trading activity. In the GARCH model for the NSE futures market the coefficient of the time-to-maturity variable is found to be insignificant, implying that time-to-maturity does not impact volatility in this market. Further the results strongly support 'Mixture of Distributions Hypothesis' in the NSE futures market. The study finally concludes that a future trading volume is a significant determinant of futures price volatility while time-to-maturity is not.
\end{abstract}

Keywords: maturity effect, futures volatility and GARCH model

\section{Introduction}

The relationship between time to maturity, volume and futures volatility has received considerable attention in financial literature, because, it has wide implications for investors, option pricing and portfolio management. Further, this relationship is significant to hedging futures contracts and margin setting. The desired margin amount is dependent on futures price volatility. Therefore, if volatility increases near delivery, margin needs to be set higher and hedging strategies also need to be monitored and adjusted. Also volatility is one of the determinants the prices of options and futures; the effect of time to maturity on volatility needs to be considered in the pricing of options and futures. Therefore it is important to study the inter-relationship between time to maturity and futures price volatility.

Samuelson (1965) provided first theoretical model for relationship between maturity effects and futures price volatility, known as Samuelson maturity hypothesis. It explains that when maturity of a derivative contract nears, volatility of the derivative's prices would increase. In other words, there is a negative relationship between time to maturity and futures volatility. Some studies have investigated Samuelson maturity hypothesis with empirical data. The studies found mixed evidence of the time-to-maturity effect and volatility in futures market. For instance, Beaulieu et al. (1998), Allen and Cruickshank (2000), Christos et al. (2006), Wang and Liu, (2008), Verma and Vijaya Kumar (2010), support the Samuelson Hypothesis, both for commodity futures markets as well as financial futures markets. Christos et al. (2006) examine the relationship between daily volatility and time to maturity in the Greek futures markets using GARCH model. They concluded that Samuelson's Hypothesis is valid, and therefore, volatility of futures prices increases as maturity of futures contracts nears. Verma and Vijaya Kumar (2010) also examined the maturity effect in the Indian Commodities Futures Market. They found that maturity effect is present and it is explained to a large extent by the negative co-variance between time-to-maturity and volatility. 
However, some studies have not supported Samuelson maturity hypothesis (Galloway \& Kolb, 1996; Han et al., 1999; Daal, 2003; Pedro \& Herrer, 2007; Kalev \& Nhan, 2007; Duong et al., 2008). Bessembinder et al. (1996) argue that maturity of futures contracts had no significant influence on their price volatility. Chen et al. (1999) document that the volatility of the Nikkei-225 index futures declines as maturity of futures contracts nears. Kalev and Huu Nhan (2007) examine the Samuelson Hypothesis in agriculture and financial futures by utilizing a nonparametric test. In their study Samuelson hypothesis is supported for agricultural futures while it is not supported for metal and financial futures. Pedro and Herrer (2007) investigate the impact of time to maturity on interest rate futures market in Mexico. They find that though maturity effects were present in some periods there was no evidence of maturity effect when all contracts were considered.

The study also investigates relationship between trading volume and volatility in financial futures markets, which is known as 'Mixture of Distribution Hypothesis' (Epps, 1976; Harris, 1986). Many studies have examined this issue. (e.g., Brailsford, 1994; Deo et al., 2008; Kumar \& Pandey, 2010). Sakthivel and Kamaiah (2009) argue that the volatility increases with unexpected trading volume and unexpected change in the open interest in Nifty Futures market. On the other hand expected futures trading volume and expected open interest, which reduces spot market volatility. Boubaker and Makram (2011) investigate the relationship between trading volume and volatility in the Tunis stock market. The results show that 'Mixture of Distribution Hypothesis' (MDH) holds true in the Tunis stock market, implying a positive relationship between futures trading volume and volatility. Other studies however, argue that trading volume has no impact on volatility in futures markets (Smith, 1989; Santoni, 1987; Rahman, 1995; Watannabe 2001).

The main objective of the study is to analyze the relationship between time to maturity, volatility and trading volume in Nifty Futures market by employing GARCH framework. We incorporate in the GARCH model, a maturity variable and two other variables for trading volume and open interest.

\section{Some Empirical Evidence}

Many studies have investigated the determinants of volatility in the derivative markets. These studies show that trading volume and maturity are important determining factors of price volatility. Bessembinder and Seguin (1993) find that trading volume has a positive relationship with volatility-as trading volume increases, volatility also increases. Herbert (1995) examines the relationship between time to maturity, volatility and the volume of trading in the gas futures contact. Using regression analysis, it is found that trading volume explains volatility more than maturity day effect in most of the derivative markets.

Similarly, Bhar and Malliaries (1998) investigate trading volume, price, short and long-term relationships between price and volume and the determinants of trading volume in foreign currency futures. They use five currency futures namely, British Pound, Canadian Dollar, Japanese Yen, German Mark and Swiss Franc. They collect data for nearby futures contracts for the period from May 1972 to November 1994. They find that in all the five currencies, the price volatility is a determinant of trading volume. David Walls (1999) examines how trading volume and time-to-time maturity impact volatility of electricity futures markets by employing regression analysis. The results show that maturity effects are present in electricity futures. Further, the results reveal that maturity effect seems to be higher in electricity futures than in other oil futures such as crude oil, heating oil and unleaded gasoline. Moosa and Bollen (1999) investigate the maturity effect using the intraday on S\&P 500 futures contract from January 1993 to December 1995. They find evidence for the absence of the maturity effect in financial futures prices.

Allen and Cruickshank (2000) investigate the maturity effect in commodity futures contracts on the Singapore International Monetary Exchange, the Sydney Futures Exchange, the London International Financial Futures and Options Exchange. Using regression analysis, they find that the maturity effects are present in a majority of the futures and options contracts. Employing GARCH framework, Rita Madarassy (2003) examines the volatility dynamics of the financial futures returns. The volatility determining factors such as time-to-maturity; open interest and trading volume are included in conditional variance equation to examine whether these variables determine futures volatility or not. The results indicate that lagged trading volume and open interest are directly related to volatility in many of these financial futures but they do not fully capture the estimated conditional variance.

Ripple and Moosa (2007) investigate the volatility of crude oil futures prices. Their results show that trading volume and open interest are major determinants of volatility in the futures market. The final result suggests that Samuelson-maturity holds true in crude oil futures contracts. While the results support earlier findings of positive and significant role for trading volume, they also show the importance of open interest as a determinant of volatility. Duong et al. (2008) test if the futures price volatility increases as maturity of contracts nears by 
employing OLS regressions and the Jonckheere-Terpstra test. The study uses intraday data from a sample of 20 energy, metals, agricultural, and financial futures markets in six futures exchanges. The results strongly support the Samuelson hypothesis in agricultural futures. But they found that Samuelson hypothesis does not hold good for any of the metals, energy or financial futures.

Using GARCH model, Kumar and Ajay Pandey (2010), investigate the impact of futures trading activity on volatility in Indian commodity derivatives market. Trading volume and open interest are used as proxies for futures trading activity. Their results show that trading volume has a positive impact on volatility in commodity futures market. It is found that although volume parameters are significant, volatility is mainly explained through its own lagged values. Finally the results reveal that open interest has no impact on volatility in most of the futures contracts.

Though there are quite a few studies in the literature focusing on the price volatility-maturity relationship, they are largely confined to the developed markets. In the context of emerging economies like India, there is no study highlighting this relationship. Hence, the present study is undertaken. Having adopted the GARCH framework of analysis, the study is intended to verify the Samuelson maturity hypothesis and 'mixture of distributions' hypothesis.

\section{Data and Methodology}

\subsection{Data Description}

The data for the present study has been obtained from the National Stock Exchange of India (NSE) website. The daily prices, volume and open interest data of Nifty Futures contracts are collected from July $4^{\text {th }}, 2003$ to November $28^{\text {th }}, 2012$. Besides, the study has chosen 10 individual stock futures and collected their daily closing price, volume and open interest data. These individual stocks futures are ACC, INFOSYS, HCLTECH, HEROHONDA, ITC, M\&M, RANBAXY, RELIANCE, SBI and TATAPOWER. Daily closing price of near-month futures contracts or nearest delivery-month is used for analysis. The study considers volume and open interest as proxies for futures trading activity.

Volume is the total number of futures contracts purchased and sold during particular day. Open interest can be defined the total number of contracts outstanding on any particular day. Time-to-maturity refers to the number of calendar days' remaining for the maturity of the futures contracts. The last day of the maturity month can be referred to as 'zero days left to maturity.' The study constructs data sample for time-to-maturity five days before the maturity date.

\subsection{Methodology}

To determine whether a series is stationary or non-stationary, Augmented Dickey Fuller (1979) and Philips Perron tests are employed. Then the GARCH family techniques are used to investigate time to maturity and volume effects on volatility of Nifty Futures as well as individual stock futures. The Autoregressive Conditional Heteroscedasticity (ARCH) model proposed by Engle (1982) and later generalized by Bollerslev (1986) has been widely used in financial literature to capture time-varying conditional volatility. The GARCH model not only captures time-varying volatility but also volatility shocks persisting over time. The GARCH $(1,1)$ regression model is obtained by:

$$
\begin{gathered}
\mathrm{R}_{\mathrm{t}}=\beta_{0}+\beta_{1} \mathrm{R}_{\mathrm{t}-1}+\varepsilon_{\mathrm{t}}, \varepsilon_{\mathrm{t}} \mid \Psi_{\mathrm{t}-1} \sim \mathrm{N}\left(0, \mathrm{~h}_{\mathrm{t}}\right) \\
h_{t}=\alpha_{0}+\sum \alpha_{1} \varepsilon_{t-1}^{2}+\sum \beta_{1} h_{t-1}
\end{gathered}
$$

Where, $R_{t}$ is $\log$ return conditional on past information, which is proxy by $R$ and $\alpha_{0}, \alpha_{1}$ and $\beta_{1}$ are the parameters to be estimated. $\Psi \mathrm{t}-1$ is the information set time $\mathrm{t}_{-1}, \varepsilon_{\mathrm{t}}$ is the stochastic error conditional on $\Psi \mathrm{t}-1$ and is assumed to have normally distribution with zero mean and conditional (time varying) variance.

\subsection{Volatility, Volume and Open Interest Relationship}

In order to examine the relationship between trading activity and volatility in Nifty Futures market the futures trading variables, namely volume and open interest are introduced in GARCH conditional equation. The model is specified as:

$$
\begin{aligned}
& \mathrm{R}_{\mathrm{t}}=\beta_{0}+\beta_{1} \mathrm{R}_{\mathrm{t}-1}+\varepsilon_{\mathrm{t}}, \varepsilon_{\mathrm{t}} \mid \Psi_{\mathrm{t}-1} \sim \mathrm{N}\left(0, \mathrm{~h}_{\mathrm{t}}\right) \\
& h_{t}=\alpha_{0}+\sum \alpha_{1} \varepsilon_{t-1}^{2}+\sum \beta_{1} h_{t-1}+\delta_{1} v o l+\delta_{2} o i
\end{aligned}
$$

Where, Vol and OI are futures volume and open interest respectively. If 'mixture of distributions hypothesis' holds true, coefficient of $\delta_{1}$ should be positive and significant. According to the 'mixture of distributions hypothesis' there exists a positive relationship between volume and price volatility. 


\subsection{Maturity Effect on Futures Volatility}

Since, the study proposes to examine the relationship between time-to-maturity and volatility in Nifty index futures, time-to-maturity (TTM) variable is included as exogenous explanatory variable in the conditional variance equation. The study mainly intends to test whether time to maturity is the only determinant of volatility in the NSE futures market or if there are also other variables that play a role in determining futures volatility. For this purpose, the study includes volume and open interest into GARCH variance equation. The inclusion of volume of trade as an explanatory variable significantly reduces the explanatory power of time to maturity. The modified GARCH model can be written as follows.

$$
\begin{aligned}
& \mathrm{R}_{\mathrm{t}}=\beta_{0}+\beta_{1} \mathrm{R}_{\mathrm{t}-1}+\varepsilon_{\mathrm{t}}, \varepsilon_{\mathrm{t}} \mid \Psi_{\mathrm{t}-1} \sim \mathrm{N}\left(0, \mathrm{~h}_{\mathrm{t}}\right) \\
& h_{t}=\alpha_{0}+\sum \alpha_{1} \varepsilon_{t-1}^{2}+\sum \beta_{1} h_{t-1}+\delta_{1} v o l+\delta_{2} o i+\theta_{1} t t m
\end{aligned}
$$

where TTM, Vol and OI are time to maturity, futures volume and open interest. For the Samuelson hypothesis to hold good the time to maturity coefficient has to be negative implying that price volatility increases as the number of days till contract maturity decreases.

\section{Empirical Results}

\begin{tabular}{|c|c|c|c|c|c|c|c|}
\hline $\begin{array}{l}\text { Name of the } \\
\text { Index }\end{array}$ & $\begin{array}{l}\text { ADF in } \\
\text { level }\end{array}$ & $\begin{array}{l}\text { ADF in } \\
\text { Differences }\end{array}$ & First & $\begin{array}{l}\text { Phillips-Perron test in } \\
\text { level }\end{array}$ & $\begin{array}{l}\text { Phillips-Perron } \\
\text { Differences }\end{array}$ & in & First \\
\hline Nifty Futures & $\begin{array}{l}-0.8523 \\
(0.3598)\end{array}$ & $\begin{array}{l}-16.6901^{*} \\
(0.0000)\end{array}$ & & $\begin{array}{l}-1.0892 \\
(0.4520)\end{array}$ & $\begin{array}{l}-16.7820^{*} \\
(0.0000)\end{array}$ & & \\
\hline $\begin{array}{l}\text { Futures } \\
\text { Volume }\end{array}$ & $\begin{array}{l}-1.5630 \\
(0.2369)\end{array}$ & $\begin{array}{l}-19.2460 * \\
(0.0000)\end{array}$ & & $\begin{array}{l}-0.8520 \\
(5.2390)\end{array}$ & $\begin{array}{l}-20.7760 * \\
(0.0000)\end{array}$ & & \\
\hline Open Interest & $\begin{array}{l}-0.5231 \\
(0.6521)\end{array}$ & $\begin{array}{l}-32.9630 * \\
(0.0000)\end{array}$ & & $\begin{array}{l}-1.8960 \\
(0.4520)\end{array}$ & $\begin{array}{l}-33.0063 * \\
(0.0000)\end{array}$ & & \\
\hline $\begin{array}{l}\text { Time } \\
\text { Maturity }\end{array}$ & $\begin{array}{l}-4.8960 * \\
(0.0852)\end{array}$ & $\begin{array}{l}-27.8961 * \\
(0.0000)\end{array}$ & & $\begin{array}{l}-5.0896^{*} \\
(0.048)\end{array}$ & $\begin{array}{l}-28.0850 * \\
(0.0000)\end{array}$ & & \\
\hline
\end{tabular}

Table 1. Results of unit root test

Note*: Indicates that unit root rejection of null hypotheses

Table 2. Results of unit root test

\begin{tabular}{llllll}
\hline $\begin{array}{l}\text { Name of the Stock } \\
\text { Futures }\end{array}$ & $\begin{array}{l}\text { ADF in } \\
\text { level }\end{array}$ & $\begin{array}{l}\text { ADF in } \\
\text { Differences }\end{array}$ & First & $\begin{array}{l}\text { Phillips-Perron test } n \\
\text { level }\end{array}$ & $\begin{array}{l}\text { Phillips-Perron test in First } \\
\text { Differences }\end{array}$ \\
\hline RELIANCE & -1.123 & $-26.871^{*}$ & -1.015 & $-25.622^{*}$ \\
& $(0.285)$ & $(0.0000)$ & $(0.2378)$ & $(0.0001)$ \\
ACC & -0.787 & $-35.417^{*}$ & -09.385 & $-26.485^{*}$ \\
& $(0.428)$ & $(0.0000)$ & $(0.305)$ & $(0.000)$ \\
SBI & -1.256 & $-20.231^{*}$ & -1.053 & $-46.075^{*}$ \\
& $(0.378)$ & $(0.000)$ & $(0.211)$ & $(0.0001)$ \\
TATAPOWER & -1.189 & $-35.852^{*}$ & -1.374 & $-26.410^{*}$ \\
& $(0.483)$ & $(0.0000)$ & $(0.0000)$ & $(0.0001)$ \\
HCL & -2.874 & $-31.512^{*}$ & -1.621 & $-47.120^{*}$ \\
& $(0.185)$ & $(0.0000)$ & $(0.514)$ & $(0.0000)$ \\
HEROHONDA & -1.198 & $-13.745^{*}$ & -1.258 & $-13.985^{*}$ \\
& $(0.486)$ & $(0.0000)$ & $(0.314)$ & $(0.0001)$ \\
INFOSYS & -1.258 & $-78.125^{*}$ & -1.234 & $-79.412^{*}$ \\
& $(0.223)$ & $(0.0000)$ & $(0.578)$ & $(0.0001)$ \\
I T C Ltd & -1.785 & $-18.782^{*}$ & -0.778 & $-19.782^{*}$ \\
& $(0.0000)$ & $(0.0000)$ & $(0.548)$ & $(0.0001)$ \\
M \& M Ltd. & -0.789 & $-11.785^{*}$ & -1.389 & $-11.876^{*}$ \\
RANBAXY & $(0.458)$ & $(0.0000)$ & $(0.475)$ & $(0.0001)$ \\
& -2.785 & $-15.378^{*}$ & -1.004 & $-16.988^{*}$ \\
\end{tabular}

Note*: Indicates that unit root rejection of null hypotheses 
To check for stationarity in Nifty Futures and individual stock futures data series, augmented Dickey-Fuller test and Phillips-Perron test tests are employed. The unit root results are presented in Table 1. The log Nifty Futures series are found to non-stationary in level form. However, $\log$ Nifty futures series is stationary in first difference. In case of futures volume and open interest are non-non-stationary in level form but are stationary in first difference. The unit root results for individual stock futures are given in Table 2. The individual stock futures, non-stationarity is found in level 1 form, but stationarity is observed in first differences.

Table 3. Descriptive statistics for nifty futures, volume and open interest

\begin{tabular}{|c|c|c|c|c|c|c|}
\hline Name of the Index & Return* & Number of Days & Mean & S.D & Skewness & Kurtosis \\
\hline \multirow{2}{*}{ Nifty Futures } & Non MD & 1850 & 0.02863 & 0.0534 & -0.8563 & 11.873 \\
\hline & MD & 97 & 0.0001 & 0.0046 & -2.594 & 3.8590 \\
\hline \multirow{2}{*}{ Futures Volume } & Non MD & 1850 & -0.0785 & 0.2561 & -7.890 & 12.853 \\
\hline & MD & 97 & -0.8546 & 0.0126 & -12.956 & 6.2356 \\
\hline \multirow{2}{*}{ Open Interest } & Non MD & 1850 & 0.0058 & 0.2523 & 5.8560 & 18.126 \\
\hline & MD & 97 & 0.7563 & 0.0895 & 0.7852 & 15.8964 \\
\hline \multicolumn{3}{|l|}{ Residuals Test } & \multicolumn{2}{|c|}{ Nifty Futures } & Futures Volume & $\begin{array}{l}\text { Open } \\
\text { Interest }\end{array}$ \\
\hline \multirow{2}{*}{ L B-Q(16) } & Non MD & 1850 & \multicolumn{2}{|l|}{24.256} & 18.569 & 37.1253 \\
\hline & MD & 97 & \multicolumn{2}{|l|}{11.239} & 47.159 & 112.563 \\
\hline \multirow{2}{*}{$\mathrm{LB}^{2}-\mathrm{Q}(16)$} & Non MD & 1850 & \multicolumn{2}{|l|}{205.895} & 186.001 & 68.520 \\
\hline & MD & 97 & \multicolumn{2}{|l|}{120.785} & 78.263 & 25.450 \\
\hline \multirow{2}{*}{ LM-(10) } & Non MD & 1850 & \multicolumn{2}{|l|}{185.120} & 785.560 & 78.563 \\
\hline & MD & 97 & \multicolumn{2}{|l|}{23.896} & 280.123 & 52.120 \\
\hline F-Test & Non MD & 1850 & \multicolumn{2}{|l|}{56.860} & 18.120 & 12.745 \\
\hline
\end{tabular}

Note: MD Implies that Maturity Day

Table 4. Descriptive statistics on individual stocks futures

\begin{tabular}{lllllll}
\hline Name of the Index/Stock & Return* & Number of Days & Mean & S.D & Skewness & Kurtosis \\
\hline \multirow{2}{*}{ RELIANCE } & Non MD & 1850 & 0.2421 & 0.03178 & -0.7852 & 4.7851 \\
& MD & 97 & -0.7852 & 0.1756 & -0.1258 & 8.7530 \\
ACC & Non MD & 1850 & 0.7452 & 0.0417 & -0.4783 & 14.852 \\
& MD & 97 & 0.0003 & 0.0589 & -1.128 & 10.394 \\
SBI & Non MD & 1850 & 0.1457 & 0.0058 & 0.1758 & 5.185 \\
& MD & 97 & 0.001 & 0.0785 & -0.842 & 2.526 \\
TATAPOWER & Non MD & 1850 & 0.472 & 0.4750 & 0.854 & 89.102 \\
& MD & 97 & 0.8630 & 0.0056 & 0.987 & 410.235 \\
HCL & Non MD & 1850 & -0.5820 & 0.0783 & -8.253 & 85.660 \\
& MD & 97 & 0.0058 & 0.0047 & -5.741 & 107.521 \\
HEROHONDA & Non MD & 1850 & 0.0052 & 0.1051 & -0.169 & 3.933 \\
INFOSYS & MD & 97 & -0.0025 & 0.0243 & -0.853 & 19.128 \\
& Non MD & 1850 & 0.0689 & 0.0852 & 6.253 & .814 \\
I T C Ltd & MD & 97 & 0.00084 & 0.0281 & -2.918 & 85.149 \\
& Non MD & 1850 & 0.0043 & 0.00759 & 12.264 & 537.4 \\
M\& M Ltd. & MD & 97 & -0.0118 & 0.1862 & -4.598 & 38.478 \\
& Non MD & 1850 & -0.0008 & 0.0702 & -78.861 & 785.10 \\
RANBAXY & MD & 97 & -0.0159 & 0.3024 & -6.863 & 63.642 \\
& Non MD & 1850 & 0.0086 & 0.00548 & -11.785 & 216.56 \\
& MD & 97 & 0.0752 & 0.0963 & 5.069 & 112.158 \\
\hline
\end{tabular}

Note: MD Implies that Maturity Days 
The descriptive statistics of the Nifty Futures are given in Table 3. The Nifty Futures return series are skewed and leptokurtic. The coefficient of skewness is negative for Nifty Futures volume for both the maturity as well as the non-maturity day's periods. It indicates that frequency distribution of the return series is negatively skewed. However, coefficient of skewness is found to be positive for open interest during maturity as well as non-maturity days. The LB-Q statistics show high and significant autocorrelation in Nifty futures returns and squared futures returns. Finally, LM tests observed the presence of ARCH effects in Nifty futures series.

Table 4 provides the descriptive statistics for all the individual stock futures for both maturity and non-maturity days. The daily mean returns for eight individual stocks futures are positive except in case of HCL and M \& M particularly during non-maturity days. In case of maturity days, daily mean returns for most of individual stock futures are also found to be positive with exception of HEROHONDA, ITC, RELIANCE and M\& M. The value of kurtosis exceeds three for most of the individual stock futures both on maturity and non-maturity days. It indicates that returns of most individual stocks deviate from the normal distribution. The values of skewness coefficients are negative for most of the individual stock futures implying that the frequency distribution of returns series is negatively skewed both during maturity days as well as non-maturity days.

Table 5. Results of GARCH $(1,1)$ model

\begin{tabular}{llll}
\hline Mean Equation & & & \\
\hline Parameters & Coefficients & Z-statistic & -value \\
\hline$\beta_{0}$ & 0.04289 & $2.1289^{*}$ & 0.0259 \\
$\beta_{1}$ & 2.8423 & $3.892^{*}$ & 0.0012 \\
\hline Variance Equation & & & \\
\hline$\alpha_{0}$ & 0.1239 & $2.8963^{*}$ & 0.0000 \\
$\alpha_{1}$ & 0.6930 & $8.7524^{*}$ & 0.0000 \\
$\beta_{1}$ & 0.4396 & $4.9630^{*}$ & 0.0000 \\
\hline Residual diagnostics & Test statistic & p-value & \\
\hline L B-Q(16) & 112.60 & 0.000 & \\
LB $-\mathrm{Q}(16)$ & 210.36 & 0.000 & \\
LM-(10) & 7.8963 & 0.0239 & \\
\hline
\end{tabular}

Note: $*$ Indicates $1 \%$ significance level

Table 6. Estimates of $\operatorname{GARCH}(1,1)$ with futures volume and open interest

\begin{tabular}{llll}
\hline Mean Equation & & & \\
\hline Parameters & Coefficients & Z-statistic & p-value \\
\hline$\beta_{0}$ & 0.7856 & $3.843^{*}$ & 0.0000 \\
$\beta_{1}$ & 2.4836 & $6.523^{*}$ & 0.0000 \\
\hline Variance Equation & & & \\
\hline$\alpha_{0}$ & 0.0146 & $3.4860^{*}$ & 0.0000 \\
$\alpha_{1}$ & 0.4853 & $8.2390^{*}$ & 0.0000 \\
$\beta_{1}$ & 0.4023 & $9.850^{*}$ & 0.0000 \\
$\delta_{1}$ (Futures Volume) & 0.4286 & $3.753^{*}$ & 0.0000 \\
$\delta_{2}$ (Open Interest) & 0.0893 & $2.856^{*}$ & 0.0000 \\
\hline Residual diagnostics & Test statistic & P. value & \\
\hline L B-Q(16) & 5.890 & 0.5230 & \\
LB ${ }^{2}$-Q(16) & 3.852 & 0.6459 & \\
LM-(10) & 2.856 & 0.4236 & \\
F-Test & 0.279 & 0.556 & \\
\hline
\end{tabular}

Note: * Indicates $1 \%$ significance level. 
Results of GARCH $(1,1)$ Model are given in Table 5. The results show the sum of $\alpha_{1}+\beta_{1}$ is close to 1 for the Nifty Futures. This result indicates a high persistence in the conditional variance of Nifty Futures. All parameters are statistically significant. Table 6 presents result of GARCH model with futures volume and open interest. The results show that estimated coefficient of futures trading volume is positive $(0.0403)$ and significant which indicates that there is a positive relationship between volatility and trading volume in Nifty Futures market. These results show that information flow (Trading volume is taken as a proxy for information flow.) has a positive significant impact on volatility-as flow of information increases, volatility also increases. To sum up, there is a positive relationship between volatility and open interest in Nifty Futures market. Higher the open interest the higher is the volume of trade expected, and this in turn leads to higher current futures price volatility. The more the future trade, the more is the opportunity for the prices to move into higher or lower levels. Finally, results show that inclusion of trading volume and open interest in GARCH model reduces the persistence of volatility.

The results of the individual stock futures are given in Table 7. The results reveal that the coefficient of futures volume is positively significant for most of stock futures with the exception of ITC and RANBAXY. There is a positive relationship between open interest and volatility of individual stock futures with the exception of TATAPOWER and HEROHONDA. Therefore, these results support the 'mixture of distributions' hypothesis in NSE futures markets. The results also suggest that information-based effect such as volume is an important determinant of futures price volatility.

Table 7. Results of GARCH $(1,1)$ model with volume and open interest

\begin{tabular}{llllllll}
\hline Mean Equation & & \multicolumn{7}{l}{ Variance Equation } \\
Name of Stock & Constant & L. return & Constant & ARCH(1) & GARCH(1) & Volume & Open Interest \\
\hline \multirow{2}{*}{ RELIANCE } & 0.0002 & 0.526 & 0.00589 & 0.3986 & 0.6452 & $0.1052^{*}$ & 0.2890 \\
& $(1.783)$ & $(2.186)$ & $(3.789)$ & $(5.631)$ & $(2.893)$ & $(2.254)$ & $(4.581)$ \\
ACC & 0.0051 & 1.0125 & 0.0059 & 0.4051 & 0.6120 & $0.0523^{*}$ & 0.0004 \\
& $(2.856)$ & $(3.590)$ & $(1.479)$ & $(2.893)$ & $(6.527)$ & $(3.4859)$ & $(0.829)$ \\
SBI & 0.0286 & 4.0051 & 0.7861 & 0.3820 & 0.6301 & $0.0086^{*}$ & $0.1265^{*}$ \\
& $(0.015)$ & $(6.456)$ & $(1.896)$ & $(1.586)$ & $(7.166)$ & $(2.856)$ & $(3.259)$ \\
TATAPOWER & 0.2590 & 0.0023 & 0.0012 & 0.2830 & 0.728 & $0.0089^{*}$ & $-0.0570^{*}$ \\
& $(1.085)$ & $(0.826)$ & $(1.962)$ & $(4.593)$ & $(11.452)$ & $(3.157)$ & $(-4.236)$ \\
HCLTECH & $2.58 \mathrm{E} 04$ & 2.239 & 0.0004 & 0.5423 & 0.5020 & $1.1890^{*}$ & $0.212^{*}$ \\
& $(3.486)$ & $(4.875)$ & $(0.586)$ & $(4.893)$ & $(8.893)$ & $(5.576)$ & $(2.842)$ \\
HEROHONDA & 0.0175 & 1.893 & 0.0075 & 0.3180 & 0.7065 & $0.953^{*}$ & -0.078 \\
& $(0.0681)$ & $(4.568)$ & $(2.786)$ & $(4.782)$ & $(9.153)$ & $(5.826)$ & $(-1.011)$ \\
INFOSYS & $3.29 \mathrm{SE} 05$ & 0.0564 & 0.0046 & 0.0845 & 0.8450 & $0.0034^{*}$ & 0.0052 \\
& $(0.9486)$ & $(2.702)$ & $(2.853)$ & $(1.896)$ & $(12.560)$ & $(2.432)$ & $(0.880)$ \\
ITC & 0.0258 & 2.159 & 0.0006 & 0.6013 & 0.482 & 0.0002 & $0.0956^{*}$ \\
& $(1.956)$ & $(9.596)$ & $(1.056)$ & $(7.586)$ & $(11.259)$ & $(0.220)$ & $(4.623)$ \\
M\&M & 0.0005 & 3.1587 & $8.25 \mathrm{E}-05$ & 0.3450 & 0.7270 & $0.9263^{*}$ & $0.8142^{*}$ \\
& $(2.583)$ & $(5.934)$ & $(4.821)$ & $(0.0456)$ & $(12.230)$ & $(6.352)$ & $(.201)$ \\
RANBAXY & 0.2900 & 2.1253 & 0.0080 & 0.4690 & 0.478 & -0.0032 & $1.0354^{*}$ \\
& $(0.658)$ & $(3.123)$ & $(1.586)$ & $(3.569)$ & $(8.00)$ & $(-0.957)$ & $(2.88)$ \\
\hline
\end{tabular}

Note: Figures in parentheses are $t$ values; * Indicates $1 \%$ level of significance

Results of time to maturity effects are given Table 8 . The results show that maturity coefficient is statistically insignificant while trading volume is positive and significant even after maturity variable is included in the GARCH variance equation. These results show that volume of trade plays an important role in explaining futures returns volatility rather than time to maturity. Further the empirical results suggest that Samuelson maturity hypothesis does not hold good in Nifty futures market. However, coefficient of open interest found to be negative and significant after inclusion of maturity variable in the conditional variance equation. In other words, open interest has a negative relationship with volatility in the Nifty futures market. 
Table 8. Empirical results of time to maturity effect with $\operatorname{GARCH}(1,1)$ model

\begin{tabular}{llll}
\hline Mean Equation & & & \\
\hline Parameters & Coefficients & Z-statistic & -value \\
\hline$\beta_{0}$ & 0.0452 & $2.852^{*}$ & 0.0000 \\
$\beta_{1}$ & 1.9863 & $8.856^{*}$ & 0.0000 \\
\hline Variance Equation & & & \\
\hline $\boldsymbol{\alpha}_{0}$ & 0.00563 & $2.852^{*}$ & 0.0000 \\
$\alpha_{1}$ & 0.29630 & $10.935^{*}$ & 0.0000 \\
$\beta_{1}$ & 0.58204 & $11.982^{*}$ & 0.0000 \\
$\delta_{1}$ (Futures Volume) & 0.04280 & $2.763^{*}$ & 0.0000 \\
$\delta_{2}$ (Open Interest) & -0.5239 & $-4.523^{*}$ & 0.000 \\
$\delta_{3}$ (Maturity Effect) & 0.00129 & 0.8746 & 0.5865 \\
\hline Residual diagnostics & Test statistic & P. value & \\
\hline L B-Q(16) & 6.520 & 0.423 & \\
LB ${ }^{2}$-Q(16) & 4.824 & 0.723 & \\
LM-(10) & 7.853 & 0.851 & \\
F-Test & 0.279 & 0.556 & \\
\hline
\end{tabular}

Note: * Indicates $1 \%$ significance level.

Table 9. Results of maturity effect with GARCH $(1,1)$ model

\begin{tabular}{lllllllll}
\hline Mean Equation & & & \multicolumn{7}{c}{ Variance Equation } \\
Name of the stock & Constant & L. return & Constant & $\begin{array}{l}\text { ARCH } \\
(1)\end{array}$ & $\begin{array}{l}\text { GARCH } \\
(1)\end{array}$ & Volume & Open Int. & TTM \\
\hline \multirow{2}{*}{ RELIANCE } & 0.0523 & 0.230 & 0.0018 & 0.2563 & 0.5060 & $0.0852^{*}$ & $-0.602^{*}$ & 0.0058 \\
& $(1.235)$ & $(1.580)$ & $(4.852)$ & $(5.055)$ & $(5.235)$ & $(3.880)$ & $(-2.068)$ & $(0.399)$ \\
ACC & 0.523 & 2.256 & 3.5 SE03 & 0.4290 & 0.5042 & $0.920^{*}$ & $-0.936^{*}$ & 0.0026 \\
& $(2.035)$ & $(3.248)$ & $(0.978)$ & $(3.256)$ & $(8.230)$ & $(2.693)$ & $(-2.856)$ & $(0.268)$ \\
SBI & 0.850 & 1.4503 & 0.0483 & $0.3805^{*}$ & 0.7802 & $0.953^{*}$ & $-2.720^{*}$ & $-0.205^{*}$ \\
& $(1.235)$ & $(3.856)$ & $(4.523)$ & $(5.230)$ & $(9.740)$ & $(3.156)$ & $(-4.854)$ & $(-2.33)$ \\
TATA POWER & 0.5805 & 2.350 & 0.0001 & 0.5210 & 3.852 & $0.0214^{*}$ & $-0.330^{*}$ & 0.026 \\
& $(2.887)$ & $(4.321)$ & $(0.852)$ & $(2.060)$ & $(4.520)$ & $(2.420)$ & $(-2.144)$ & $(1.079)$ \\
HCLTECH & 0.2537 & 1.8560 & -0.0051 & 0.5420 & 0.4560 & $0.7060^{*}$ & $-2.118^{*}$ & 0.0030 \\
& $(8.812)$ & $(5.253)$ & $(-5.846)$ & $(3.126)$ & $(3.5490$ & $(8.401)$ & $(2.563)$ & $(0.523)$ \\
HEROHOND & 0.8206 & 1.883 & 0.0087 & 0.3123 & 0.5296 & 0.0023 & $-0.006^{*}$ & 0.0051 \\
& $(2.852)$ & $(4.256)$ & $(2.586)$ & $(0.853)$ & $(12.180)$ & $(1.013)$ & $(-0.429)$ & $(0.823)$ \\
INFOSYS & 0.2563 & 0.5230 & 0.0060 & 0.0906 & 0.8820 & $0.523 *$ & 0.0001 & -0.0007 \\
\multirow{2}{*}{ ITC } & $(6.852)$ & $(2.523)$ & $(3.152)$ & $(2.563)$ & $(5.230)$ & $(3.120)$ & $(0.597)$ & $(-0.66)$ \\
& 0.8520 & 2.9960 & 0.852 & 0.1230 & 0.837 & 0.0005 & $-0.932^{*}$ & 0.0020 \\
M\&M & $(3.366)$ & $(4.850)$ & $(6.126)$ & $(2.501)$ & $(2.420)$ & $(0.852)$ & $(2.258)$ & $(0.342)$ \\
& 0.560 & 0.852 & 0.563 & 0.3650 & 0.380 & $0.4230^{*}$ & 0.0029 & 0.0006 \\
RANBAXY & $(2.2359)$ & $(2.856)$ & $(0.856)$ & $(4.852)$ & $(5.006)$ & $(6.823)$ & $(0.723)$ & $(0.934)$ \\
& 0.8520 & 5.1290 & 0.8520 & 0.5230 & 0.2960 & 0.0520 & 0.0612 & 0.0008 \\
& $(2.265)$ & $(7.236)$ & $(2.530)$ & $(4.009)$ & $(5.239)$ & $(3.388)$ & $(1.228)$ & $(0.894)$ \\
\hline
\end{tabular}

Note: Figures in parentheses are t values; * Indicates $1 \%$ level of significance

The study also investigates the maturity effect on volatility of individual stock futures. The empirical results are given in Table 9. The results reveal that the coefficient of maturity variable is statistically insignificant for most 
individual stock futures. These results show that maturity variable does not play an important role in explaining futures volatility. Further results show that there is a positive relationship between volume and volatility of most of the individual stock futures with the exception of ITC and HEROHONDA. However, the coefficient of open interest is found to be negative and significant for most of individual stock futures with the exception of INFOSYS, ITC and RANBAXY.

\section{Concluding Remarks}

The study investigates relationship between time to maturity and volatility in NSE futures market. It also investigates 'mixture of distributions hypothesis' (Clerk, 1973; Epps, 1983), which states that futures price volatility and volume are related. Daily closing prices of Nifty Futures, volume and open interest and also ten individual stock futures are collected from the period July $4^{\text {th }}, 2003$ to November $28^{\text {th }}, 2012$ and used in analysis. The empirical analysis shows that Samuelson hypothesis does not hold in the Nifty Futures market. Further, the results show a strong support for 'mixture of distributions hypotheses in NSE futures markets. The study finally concludes that while time-to-maturity does not play an important role in explaining futures price volatility rate of information as measured by volume is an important determinant of futures price volatility. The results of the present study have important implications both for investors and regulators. Since maturity effect does not hold good in NSE futures market, the investors should not make their investment decisions based on time-to-maturity.

\section{References}

Allen, D. E., \& Cruickshank, S. N. (2000). Empirical Testing of the Samuelson Hypothesis: An Application to Futures Markets in Australia. Singapore and the UK, Working Paper 00.10. School of Finance and Business Economics-Edith Cowan University.

Beaulieu, \& Marie, C. (1998). Time to Maturity in the basis of Stock Market Indices: Evidence from the S\&P 500 and the MMI. Journal of Empirical Finance, 5(3), 177-195. http://dx.doi.org/10.1016/S0927-5398 (97)00017-0

Bessembinder, H., \& Seguin, P. J. (1993). Price Volatility, Trading Volume, and Market Depth: Evidence from Futures Markets. Journal of Financial and Quantitative Analysis, 28(1), 21-39. http://dx.doi.org/10.2307/2331149

Bessembinder, H., Coughenour, J. F., Seguin, P. J., \& Smeller, M. M. (1996). Is there a term Structure of Futures Volatilities? Reevaluating the Samuelson Hypothesis, Journal of Derivatives, 4(2), 45-58. http://dx.doi.org/10.3905/jod.1996.407967

Bhar, R., \& Malliaries. (1998). Volume and Volatility in Foreign Currency Futures Market. Review of Quantitative Finance \& Accounting, 10, 285-302. http://dx.doi.org/10.1023/A:1008253718001

Boubaker, A., \& Makram, B. (2011). The empirical relationship between stock returns volatility and trading volume: Evidence on the Tunis stock market. International Journal of Management Science and Engineering Management, 6(5), 374-381.

Brailsford, T. J. (1994). Relationship between trading volume and stock return volatility in the Australian market. Research Paper, Department of Accounting and Finance, 1-35.

Chen, Y. J., Duan, J. C., \& Hung, M. W. (1999). Volatility and Maturity Affects in the Nikkei Index Futures. Journal of Futures Markets, 19(8), 895-909. http://dx.doi.org/10.1002/(SICI)1096-9934(199912)19:8<895:: AID-FUT3>3.0.CO;2-C

Daal, E., Farhat, J., \& Wei, P. (2003). Reexamining the maturity effect using extensive futures data. Working paper University of New Orleans,

Dall, E., Farhat, J., \& Wei, P. (2003). Does futures Exhibit Maturity Effect? New Evidence from an Extensive set of US and Foreign Futures Contracts. Working Papers 2003-04, University of New Orleans.

Deo, M., \& Srinivasan. (2008). The Empirical Relationship between Stock Returns, Trading Volume and Volatility: Evidence from Select Asia-Pacific Stock Market. European Journal of Economics, Finance and Administrative Sciences, 12, 1450-2275.

Duong, H. N., \& Kalev, P. S. (2008). The Samuelson Hypothesis in Futures Markets: An Analysis using intraday data. Journal of banking and finance, 32(4), 489-500. http://dx.doi.org/10.1016/j.jbankfin.2007.06.011

Epps, T. W., \& Epps, M. L. (1976). The Stochastic Dependence of Security Price Changes and Transaction Volumes: Implication for the Mixture-of-Distributions Hypothesis. Econometrica, 44(2), 305-322. http://dx. doi.org/10.2307/1912726 
Floros, C., \& Dimitrios, V. V. (2006). Empirically investigate Samuelson's hypothesis in Greek Futures Market. Investment Management and Financial Innovations, 3(2), 154-170.

Gurrola, P., \& Herrerías, R. (2010). Maturity effect in Mexican interest rate futures. The Journal of Futures Markets, 31(4), 371-393. http://dx.doi.org/10.1002/fut.20477

Han, L. M., Kling, J. M., \& Sell, C. W. (1999). Foreign exchange futures volatility: Day-of the-week, intraday, and maturity patterns in the presence of macroeconomic announcements. Journal of Futures Markets, 19(6), 665-693. http://dx.doi.org/10.1002/(SICI)1096-9934(199909)19:6<665::AID-FUT3>3.0.CO;2-N

Harris, \& Lawrence. (1986). Cross-Security tests of the Mixture of Distributions Hypothesis. Journal of Financial and Quantitative Analysis, 21(1), 39-46. http://dx.doi.org/10.2307/2330989

Kumar, B., \& Pandey, A. (2010). Price Volatility, Trading Volume and Open Interest: Evidence from Indian Commodity Futures Markets. Retrieved from http://ssrn.com/abstract=1658844or

Madarassy, R. (2003). Maturity Effects in Futures Markets; Evidence from Eleven Financial Futures Markets. Santa Cruz Center for International Economics, University of California.

Moosa, I. A., \& Bollen, B. (2001). Is there a maturity effect in the price of the S\&P 500 futures contract? Applied Economics Letters, 8, 693-695. http://dx.doi.org/10.1080/13504850110036355

Ripple, \& Moosa, I. (2005). Futures Maturity and Hedging Effectiveness-The Case of Oil Futures. Research Papers 0513, Macquarie University, Department of Economics.

Sakthivel, \& Kamaiah. (2009). Futures Trading and Spot Market Volatility: A Case of S\&P CNX Nifty Index. GITAM Review of International Business, 1(2), 2009.

Samuelson, P. A. (1965). Proof That Properly Anticipated Prices Fluctuate Randomly. Industrial Management Review, 6, 41-49.

Santoni. (1987). Has Programmed Trading Made Stock Price Volatility. Federal Reserve Bank of St. Louis Review, 19-29.

Smith. (1989). Market Volatility: Causes and Consequences. Cornell Review, 74, 953-962.

Verma, \& Kumar, V. (2010). An Examination of the Maturity Effect in the Indian Commodities Futures Market. Agricultural Economics Research Review, 23, 335-342.

Walls, D. (1999). Volatility, Volume and Maturity in Electricity Futures. Applied Financial Economics, 9, 283-287. http://dx.doi.org/10.1080/096031099332357

Wang, \& Liu. (2008). Determinants of the volatility of futures markets price returns: The case of Chinese wheat futures, ICMSE 2008. $15^{\text {th }}$ Annual Conference Proceedings. International Conference on, 1-18.

Watanabe, T. (2001). Price volatility, trading volume, and market depth: Evidence from the Japanese stock index futures market. Applied Financial Economics, 11, 651-658. http://dx.doi.org/10.1080/096031001753266939

\section{Copyrights}

Copyright for this article is retained by the author(s), with first publication rights granted to the journal.

This is an open-access article distributed under the terms and conditions of the Creative Commons Attribution license (http://creativecommons.org/licenses/by/3.0/). 